\title{
BMJ open Can use of healthcare services among 15-16-year-olds predict an increased level of high school dropout? A longitudinal community study
}

\author{
Lisbeth Homlong, Elin O Rosvold, Ole R Haavet
}

To cite: Homlong L, Rosvold EO, Haavet OR. Can use of healthcare services among 15-16-year-olds predict an increased level of high school dropout? A longitudinal community study. BMJ Open 2013;3: e003125. doi:10.1136/ bmjopen-2013-003125

- Prepublication history for this paper is available online. To view these files please visit the journal online (http://dx.doi.org/10.1136/ bmjopen-2013-003125).

Received 25 April 2013 Revised 13 August 2013 Accepted 14 August 2013

Department of General Practice, Institute of Health and Society, University of Oslo, Oslo, Norway

Correspondence to Dr Lisbeth Homlong; lisbeth. homlong@medisin.uio.no

\section{ABSTRACT}

Objectives: To study associations between healthcare seeking in 15-16-year-olds and high school dropout 5 years later.

Design: Longitudinal community study.

Setting: Data from a comprehensive youth health survey conducted in 2000-2004, linked to data from national registries up to 2010.

Participants: 13964 10th grade secondary school students in six Norwegian counties.

Main outcome measure: Logistic regression was used to compute ORs for high school dropout.

Results: The total proportion of students not completing high school 5 years after registering was 29\% (girls $24 \%$, boys $34 \%$ ). Frequent attenders to school health services and youth health clinics at age 15-16 years had a higher dropout rate (37/48\% and $45 / 71 \%)$, compared with those with no or moderate use. Adolescents referred to mental health services were also more likely to drop out $(47 / 62 \%)$. Boys with moderate use of a general practitioner (GP) had a lower dropout rate (30\%). A multiple logistic regression analysis, in which we adjusted for selected health indicators and sociodemographic background variables, revealed that seeking help from the youth health clinic and consulting mental health services, were associated with increased level of high school dropout 5 years later. Frequent attenders ( $\geq 4$ contacts) had the highest odds of dropping out. Yet, boys who saw a GP and girls attending the school health services regularly over the previous year were less likely than their peers to drop out from high school.

Conclusions: Adolescents who seek help at certain healthcare services can be at risk of dropping out of high school later. Health workers should pay particular attention to frequent attenders and offer follow-up when needed. However, boys who attended a GP regularly were more likely to continue to high school graduation, which may indicate a protective effect of having a regular and stable relationship with a GP.

\section{INTRODUCTION}

Adolescents reporting poor health tend to have an underconsumption of healthcare facilities according to their expected need, hence a

\section{ARTICLE SUMMARY}

Strengths and limitations of this study

- The results of the study are based on a large community study with a substantial number of participants, a high response rate and few missing data.

- The prospective-longitudinal design provides a higher power than a cross-sectional design.

- The study is observational, thus one must be careful to draw conclusions about causal relationships.

- The items addressed in the baseline questionnaire are based on self-report, which can engender an underestimation of health service use and incomplete information on health.

considerable proportion of them seem to have health problems not met by healthcare professionals. ${ }^{1-3}$ Studies have suggested that only a minority of adolescents with mental health problems seek healthcare for these reasons. ${ }^{4} 5$ Nevertheless, help seekers should be considered a vulnerable group. A US study has shown that disturbed adolescents more frequently seek help from professional healthcare services than do their non-disturbed peers. ${ }^{6}$ Furthermore, adolescent frequent attenders to primary healthcare report more physical health complaints, more emotional problems and more days off school than do regular primary healthcare attenders. ${ }^{7}$

Poor mental and physical health are among several factors that can have an influence on help-seeking behaviour and at adolescents' ability to graduate from high school. ${ }^{8}{ }^{9}$ Although chronic disease in childhood has an impact on educational level and work participation in adult life, ${ }^{10}{ }^{11}$ less is known about the effects of ill health during adolescent years. ${ }^{9}$ An increasing level of mental health problems in young people, including depressive symptomatology, can play a role ${ }^{12}$ and several studies have shown associations with failure to 
complete high school. ${ }^{14}{ }^{15}$ In a recent Norwegian study, one of five high school dropouts reported that they quit because of mental health problems. ${ }^{16}$ Previous research indicates that teenage pregnancy and substance abuse are also associated with dropping out. ${ }^{17} 18$

A substantial number of adolescents drop out of high school, placing themselves at higher risk of marginalisation later in life ${ }^{819}$ and generating considerable public attention. Norway and several other western countries experience the same challenges. In Norway, adolescents normally enrol in high school at age 15-16, immediately after finishing 10th grade, which is the last year of compulsory school. Students are supposed to complete high school within 3 years. Those who fail to graduate within 5 years after registering as students are defined as high school dropouts. A recent Norwegian study has shown that high school dropouts are at higher risk than their peers of receiving social security benefits 5 years later. ${ }^{20}$ Previous studies have found a strong association between low educational level and early receipt of a disability pension. ${ }^{11}{ }^{21}$ Education is a key to participation in adult work life, and high school graduation has a strong influence on future health and well-being. ${ }^{82}$

The concept of marginalisation is often used to describe a process that in a worst-case scenario can end up in permanent exclusion. ${ }^{23}$ Dropping out of high school can be a first step in the process of marginalisation. High school dropout and marginalisation among young adults are fields that must be approached from different angles. Both individual characteristics and contextual factors related to family, friends, the community, the schools and the school system have an influence on dropout.

In our study we addressed the problem from a health-related perspective, by exploring whether adolescents at risk had made contacts with the health services already at age 15-16 years. Help-seeking behaviour cannot be explored without including health and sociodemographic background factors. As we consider help seekers a vulnerable group, the aim of our study was to determine whether adolescent help seekers also have increased odds of high school dropout in a longitudinal perspective.

\section{METHODS}

Population

A comprehensive health survey of all 10th grade secondary school students (aged 15-16 years) in six Norwegian counties, was conducted between 2000 and 2004. The youth survey was initiated in Oslo in 2000 and was extended to include five more counties in the following years, 2001-2004. Originally 1842510 th graders were invited to the baseline studies, while the overall response rate was $87 \%(\mathrm{n}=15966)$. The study was organised as a classroom survey, where the pupils filled a written questionnaire during two school hours. An assistant was present to provide information to the participants and administer the questionnaires. Pupils not present at school at the day of the survey were left questionnaires at the schools to be filled out later. Those not responding, received a copy by mail to their home address along with a stamped return envelope.

Participation in the survey was voluntary and the pupils signed an informed consent in advance. The survey comprised questions about relationships with family, friends and school; physical and mental health; health behaviour and life events. ${ }^{24}$ More detailed information about the health survey is available on the website of the Norwegian Institute of Public Health. ${ }^{25}$

Questionnaire data from the study were linked to data from the National Education Registry and the National Insurance Services (NIS/FD-trygd), compulsory national databases which supply detailed information on the entire cohort up to the year 2010. A precise linkage of records was possible because of the national identification number given to every resident of Norway. After linkage by Statistics Norway, the national identification numbers were removed from the data sets and kept within a safe computer system to secure anonymity for each individual. At baseline, the adolescent contributors to the questionnaires were asked for their consent to link the data from the questionnaires to national registers at a later date; $90 \%$ of the 15966 in our baseline population agreed $(\mathrm{n}=14062)$.

From the NIS we obtained information on participants who were granted an early-permanent disability benefit $(n=55)$ during the follow-up period. We excluded those individuals from the study, as a majority were diagnosed with mild-to-moderate mental retardation, diagnoses within the autistic spectrum or severe psychiatric disorders like schizophrenia-conditions which were not compatible with high school graduation.

Participants who died $(n=43)$ during follow-up time were also excluded from the analyses, leaving us with a total study group of $n=13964$.

\section{Ethics}

The study was approved by the regional committee for Medical and Health Research Ethics and by the Norwegian Data Inspectorate. These institutions gave permission for the use and linkage of the data. The adolescent participants gave a written consent to link their questionnaire data to national registers at a later date.

\section{Variables}

High school dropouts

From the National Education Registry, we obtained information on adolescents who had failed to complete high school, which is the main outcome variable in this article. In Norway, adolescents normally enrol in high school at age 15-16 years, immediately after finishing 10th grade, which is the last year of compulsory schooling in Norway. Students are expected to complete high school within 3 years. Those who did not graduate within 5 years after registering as high school students are defined for the purposes of this study as high school dropouts. ${ }^{26}$ 


\section{Use of healthcare services}

In the baseline questionnaires, participants answered questions about help seeking from the healthcare system during the 12 months prior to the survey, whether through school health services, youth health clinic, general practitioner (GP) or child and adolescent mental health services. The GP, the school health services and the youth health clinic in Norway are considered lowthreshold parts of the primary healthcare system, and are all free of charge for children and adolescents up to the age of 16 years. The services of child and adolescent mental health are paid for by the government, but a referral is required from a GP or another physician. To measure the use of healthcare services, the contributors were given three response options-'none', '1-3' or ' 4 or more'-for number of contacts during the past year. In our analyses, we aggregated contacts with the child and adolescent mental health services into two categories: 'none' or ' 1 or more' contacts. The reason for visiting any of the service providers was not measured in the questionnaires.

\section{Health indicators}

At baseline, adolescents were asked questions concerning their health, including direct questions on specific conditions. As adjustment variables we used the baseline questions addressing the adolescents' self-perceptions of the status of their general health, if they had or have had asthma or allergies, and conditions experienced in the 12 months prior to the survey: serious illness or injury, headache, abdominal pain, neck pain or shoulder pain, back pain or pain in extremities. The contributors could answer 'yes' or 'no' to these health-related and painrelated questions. Self-rated health is a health measure that can predict later morbidity, mortality, health service use and early disability. ${ }^{27}$ During adolescence, self-rated health status appears to be relatively stable, and it seems not to be changed by medical diagnoses or by mental or somatic health symptoms. ${ }^{27}$ Self-rated health is considered to have good reliability for adults. ${ }^{28}$ In the baseline questionnaire, self-rated health was categorised into four options: 'bad', 'not good', 'good' or 'very good'. In our analyses, we dichotomised this variable into two categories: 'very good or good' and 'not good or bad'. We also aggregated the pain variables into a dichotomous variable, in which three or more pain sites indicated a positive pain score and two or fewer indicated a negative pain score. We consider widespread pain to be an independent indicator of ill health. We also know from previous research that there is a certain comorbidity in adults between depressive disorders and chronic pain. ${ }^{29}$ Level of mental health problems were scored using the Hopkin's Symptom Checklist-10 (HSCL-10), a short-form of the Hopkin's Symptom Checklist-25 (SCL-25), and an instrument designed to diagnose depression in primary healthcare. ${ }^{30}$ The HSCL-10 includes 10 questions about psychological symptoms experienced over the previous week and is validated for use both in general practice and in epidemiological studies. ${ }^{31}$ A sum score above 1.6 indicates mild, moderate or severe depression among 1416-year-olds.

\section{Sociodemographics}

The sociodemographic background variables concerning parents' marital situation and household income were based on self-reports from the baseline questionnaires. The pupils were asked whether their parents' were 'married/living together', 'divorced/separated', 'one or both dead' or 'other'. We chose to dichotomise these options into 'married/living together' or 'other'. The question concerning household income were categorised into 'very good', 'good', 'mediocre' or 'poor'. Here we chose to collapse 'very good' and 'good' into one category, which we used as the reference category. Information on parents' educational level was provided by Statistics Norway. The highest accomplished educational level of one of the parents was used, leaving us with four categories: 'higher college or university degree' ( $>4$ years); 'lower college or university degree'; 'high school' or 'primary school'.

\section{Statistical analyses}

Analyses of the data set were performed using multiple logistic regression analysis in SPSS V.19.0, with high school dropout as the outcome variable. In the crude model, we tested the variables concerning health service usage separately and ORs were computed for high school dropout. In the adjusted model, use of healthcare services was adjusted for each other, for the selected health indicators and for sociodemographic background variables. All analyses were stratified by gender.

\section{RESULTS}

Girls comprised $50.3 \%$ of our study group. Descriptive data of the population are presented in table 1 . Missing data as a result of skipped questions concerning healthcare seeking varied from $0.8 \%$ to $1.6 \%$, whereas the questions on health had missing values from $1.1 \%$ to $6.5 \%$. Follow-up data indicated that $28.9 \%$ of the students did not complete high school within 5 years (girls $23.8 \%$, boys $34.2 \%$ ). The descriptive baseline material revealed that $70 \%$ of the adolescents attended one or more healthcare services over the previous year: school health services (girls $32.4 \%$, boys $16.4 \%$ ), youth health clinic (girls 21.1, boys 7.8\%), GP (girls 59.5, boys $46.5 \%)$, child and adolescent mental health services (girls 6.9, boys 3.7\%). Girls had substantially more contacts than did boys. A smaller number of the adolescents reported four or more contacts with school health services (girls 4.7 , boys $0.9 \%$ ) and the youth health clinic (girls 3.7 , boys $0.6 \%$ ), whereas $12.1 \%$ of the girls and $6.6 \%$ of the boys reported multiple contacts with a GP.

With few exceptions, adolescents who reported use of different healthcare services during the past 12 months, generally reported more health problems, compared 
Table 1 Descriptive characteristics of the study population ( $\mathrm{N}=13964)$ at baseline, 2000-2004, and at follow-up, 2010

\begin{tabular}{|c|c|c|}
\hline At baseline & $\mathbf{N}$ & Per cent \\
\hline \multicolumn{3}{|l|}{ Gender } \\
\hline Girls & 7019 & 50.3 \\
\hline Boys & 6945 & 49.7 \\
\hline \multicolumn{3}{|l|}{$\begin{array}{l}\text { Sociodemographic characteristics } \\
\text { Ethnicity }\end{array}$} \\
\hline Ethnic Norwegian & 12155 & 87.0 \\
\hline First-generation immigrant & 1126 & 8.1 \\
\hline Second-generation immigrant & 683 & 4.9 \\
\hline \multicolumn{3}{|l|}{ Parents' educational level } \\
\hline College or university degree $>4$ years & 1937 & 13.9 \\
\hline College or university degree $\leq 4$ years & 4277 & 30.6 \\
\hline High school & 5681 & 40.7 \\
\hline Primary school & 1864 & 13.3 \\
\hline Missing & 205 & 1.5 \\
\hline \multicolumn{3}{|l|}{ Parents' marital status } \\
\hline Married or living together & 9255 & 66.3 \\
\hline Other & 4600 & 32.9 \\
\hline Missing & 109 & 0.8 \\
\hline \multicolumn{3}{|l|}{ Household income } \\
\hline Very good or good & 8732 & 62.5 \\
\hline Mediocre & 4546 & 32.6 \\
\hline Poor & 457 & 3.3 \\
\hline Missing & 229 & 1.6 \\
\hline \multicolumn{3}{|l|}{ Status at follow-up } \\
\hline \multicolumn{3}{|l|}{ High school dropout } \\
\hline Total & 4040 & 28.9 \\
\hline Girls & 1668 & 23.8 \\
\hline Boys & 2372 & 34.2 \\
\hline
\end{tabular}

with those who reported no use of such health services (table 2). Among frequent attenders ( $\geq 4$ visits), a substantially higher percentage reported health problems compared with those with moderate use of services. This was the case for both girls and boys.

As shown in table 3, a higher rate of high school dropouts were observed among frequent attenders to the school health services (girls $36.5 \%$, boys $48.3 \%$ ) and the youth health clinic (girls 44.5 , boys $71.1 \%$ ), compared with those with no or moderate use (1-3 visits). Also adolescents referred to the mental health service had a higher dropout rate (girls $47 \%$, boys $62.2 \%$ ). Boys with moderate use of a GP, had a lower dropout rate $(29.8 \%)$.

Table 4 shows that visiting the child and adolescent mental health services at age 15-16 years was strongly associated with dropping out of high school 5 years later, in both genders (girls' OR 3.18, 95\% CI 2.63 to 3.84; boys $3.37,2.60$ to 4.37 ). Likewise, seeking help at the youth health clinic (1-3 contacts: girls $1.83,1.60$ to 2.10 ; boys $1.64,1.36$ to $1.97 ; \geq 4$ contacts: girls $3.06,2.37$ to 3.95 ; boys $5.02,2.48$ to 10.14 ). The associations remained significant after adjustment for use of other healthcare services, health indicators and sociodemographic variables-except for boys with moderate use of the youth health clinic. In the unadjusted analyses, attending the school health services was associated with dropping out of high school (1-3: girls 1.15, 1.01 to 1.30 ; boys $1.36,1.19$ to 1.56 ; $\geq 4$ : girls $2.02,1.59$ to 2.56 ; boys $1.93,1.16$ to 3.21 ), while after adjustments in girls, moderate use of school health services had a slightly protective effect $(0.82,0.70$ to 0.96$)$.

Between 1 and 3 contacts with the GP the previous year was associated with a lower level of high school dropout in boys $(0.73,0.65$ to 0.81$)$. Boys who were regular users of a GP also had a significant lower dropout rate in the adjusted model.

\section{DISCUSSION \\ Main findings}

Results revealed that 15-16-year-olds who attended the youth health clinic and those who saw the child and adolescent mental health services were significantly more likely to drop out of high school 5 years later than were those who did not seek help at these services. We also found that use of school health services was related to high school dropout, in both genders, but not after adjustments had been made. On the contrary, girls who reported 1-3 contacts with the school-based clinic the past year, had a slightly better outcome. Also boys who attended a GP regularly were more likely to continue to high school graduation, which may indicate a protective effect of having a regular and stable relationship with a GP.

\section{Strengths and weaknesses}

The substantial number of participants in geographically diverse areas, along with a high response rate and few missing data constitute the strengths of this prospective community study. The adolescent study sample should be representative, therefore, for a general youth population. Furthermore, the compulsory Norwegian registries provided us with complete, reliable follow-up material. The prospective longitudinal design provided the opportunity to observe a temporal order of events on an individual level, and it can be argued that the power is stronger compared with that of a cross-sectional design. One should be careful, however, not to draw conclusions about causal relationships, given the observational nature of the study.

The baseline survey was conducted in six Norwegian counties in both urban and rural areas and encompasses the entire youth population in these regions. Yet, because local variations in the accessibility of healthcare services can influence help-seeking behaviour, our results may not be applicable in all settings.

One limitation of the questions concerning healthvariables which were adjusted for in the analyses-is the lack of information they provide on the severity or chronicity of conditions. Furthermore, the help-seeking variables in the baseline survey provide no reasons for the adolescents' encounters with the health system. 
Table 2 Percentage of 15-16-year-olds reporting different health problems within type and level of reported healthcare use, all numbers stratified by gender ( $\mathrm{N}=13964)$

\begin{tabular}{|c|c|c|c|c|c|c|c|c|c|c|c|c|}
\hline & \multicolumn{2}{|l|}{ Asthma } & \multicolumn{2}{|l|}{ Allergy } & \multicolumn{2}{|c|}{$\begin{array}{l}\text { Poor self-perceived } \\
\text { health }\end{array}$} & \multicolumn{2}{|c|}{$\begin{array}{l}\text { Experienced serious } \\
\text { illness/injury past } \\
12 \text { months }\end{array}$} & \multicolumn{2}{|c|}{$\begin{array}{l}\text { Pain sites } \geq 3 \text { past } \\
12 \text { months }\end{array}$} & \multicolumn{2}{|c|}{ HSCL-10 $\geq 1.6$} \\
\hline & $\begin{array}{l}\text { Girls } \\
\text { N (\%) }\end{array}$ & $\begin{array}{l}\text { Boys } \\
\text { N (\%) }\end{array}$ & $\begin{array}{l}\text { Girls } \\
\text { N (\%) }\end{array}$ & $\begin{array}{l}\text { Boys } \\
\text { N (\%) }\end{array}$ & $\begin{array}{l}\text { Girls } \\
\mathrm{N} \text { (\%) }\end{array}$ & $\begin{array}{l}\text { Boys } \\
\text { N (\%) }\end{array}$ & $\begin{array}{l}\text { Girls } \\
\text { N (\%) }\end{array}$ & $\begin{array}{l}\text { Boys } \\
\text { N (\%) }\end{array}$ & $\begin{array}{l}\text { Girls } \\
\text { N (\%) }\end{array}$ & $\begin{array}{l}\text { Boys } \\
\text { N (\%) }\end{array}$ & $\begin{array}{l}\text { Girls } \\
\text { N (\%) }\end{array}$ & $\begin{array}{l}\text { Boys } \\
\text { N (\%) }\end{array}$ \\
\hline $\begin{array}{l}\text { Total numbers } \\
\text { reporting health } \\
\text { problems }\end{array}$ & $910(13.7)$ & 897 (13.5) & $2756(41.0)$ & 2448 (36.5) & 960 (13.9) & $645(9.4)$ & 606 (9.2) & 651 (9.9) & 2683 (40.4) & 1473 (22.3) & $2390(35.2)$ & $906(13.4)$ \\
\hline \multicolumn{13}{|c|}{ Within self-reported level of healthcare use } \\
\hline $\begin{array}{l}\text { School } h \\
\text { None }\end{array}$ & $565(12.7)$ & 726 (13.2) & 1758 (39.1) & 2008 (36.1) & 556 (12.1) & 492 (8.7) & 351 (8.0) & 498 (9.1) & 1555 (35.0) & 1135 (20.7) & 1415 (31.1) & 688 (12.2) \\
\hline $1-3$ & $270(15.0)$ & $150(14.8)$ & 821 (44.8) & $398(38.8)$ & 296 (15.7) & $132(12.5)$ & $189(10.6)$ & 133 (13.3) & 894 (48.8) & 298 (29.7) & 750 (40.3) & 194 (18.9) \\
\hline$\geq 4$ & $63(20.7)$ & 8 (13.3) & $150(48.1)$ & 20 (35.1) & 86 (26.8) & $10(16.7)$ & 54 (17.9) & 11 (19.3) & 201 (65.3) & 24 (41.4) & 200 (63.3) & $22(36.7)$ \\
\hline \multicolumn{13}{|c|}{ Youth health clinic } \\
\hline None & 671 (12.8) & 796 (13.1) & 2093 (39.6) & 2214 (36.2) & 679 (12.6) & 553 (8.8) & 433 (8.3) & 567 (9.4) & 1922 (36.8) & 1289 (21.3) & 1709 (32.1) & 786 (12.7) \\
\hline $1-3$ & 183 (16.3) & 79 (16.9) & $533(46.5)$ & $191(40.6)$ & 201 (16.9) & 70 (14.4) & 138 (12.5) & 68 (14.8) & 591 (51.8) & 150 (32.3) & $524(44.7)$ & $103(21.5)$ \\
\hline$\geq 4$ & $49(20.3)$ & $5(13.5)$ & $114(46.5)$ & 11 (30.6) & 67 (26.4) & $7(18.4)$ & 34 (14.3) & 7 (19.4) & $150(61.7)$ & 13 (36.1) & $146(57.9)$ & 12 (33.3) \\
\hline \multicolumn{13}{|c|}{ General practitioner } \\
\hline None & 237 (8.8) & 365 (10.4) & 870 (32.2) & 1128 (31.9) & 258 (9.3) & 301 (8.3) & $108(4.1)$ & $192(5.5)$ & 805 (30.2) & 605 (17.3) & 796 (29.2) & 437 (12.2) \\
\hline $1-3$ & $485(15.6)$ & 410 (15.6) & $1413(44.8)$ & $1074(40.7)$ & 466 (14.4) & 255 (9.4) & $284(9.2)$ & 314 (12.0) & 1377 (44.0) & $680(26.1)$ & 1155 (36.3) & 373 (13.9) \\
\hline$\geq 4$ & 178 (22.8) & 105 (24.4) & 450 (56.2) & 208 (47.5) & 223 (27.1) & 73 (16.2) & 211 (27.4) & 137 (32.2) & 480 (60.2) & 163 (38.6) & $422(51.7)$ & $90(20.4)$ \\
\hline \multicolumn{13}{|c|}{ Child and adolescent mental health services } \\
\hline None & $810(13.2)$ & 834 (13.2) & 2499 (40.3) & 2323 (36.3) & 793 (12.5) & $584(8.9)$ & 525 (8.6) & $601(9.6)$ & $2383(38.8)$ & $1361(21.6)$ & 2046 (32.6) & 803 (12.4) \\
\hline$\geq 1$ & $87(19.5)$ & $47(19.5)$ & $238(51.7)$ & 96 (39.8) & $147(31.5)$ & 46 (18.5) & $76(17.7)$ & $43(18.5)$ & $272(60.0)$ & $90(37.5)$ & 323 (69.5) & $96(40.5)$ \\
\hline
\end{tabular}


Table 3 Healthcare seeking behaviour and health indicators in 15-16-year-olds and percentage of high school dropout 5 years later $(\mathrm{N}=13964)$

\begin{tabular}{|c|c|c|c|c|}
\hline & \multicolumn{2}{|l|}{ Girls } & \multicolumn{2}{|l|}{ Boys } \\
\hline & $\mathbf{N}(\%)$ & Dropout (\%) & $\mathrm{N}(\%)$ & Dropout (\%) \\
\hline \multicolumn{5}{|l|}{ Self-reported level of healthcare use } \\
\hline \multicolumn{5}{|l|}{ School health services } \\
\hline None & 4690 (67.7) & 22.2 & $5728(83.6)$ & 32.7 \\
\hline $1-3$ & 1917 (27.7) & 24.6 & $1064(15.5)$ & 39.8 \\
\hline$\geq 4$ & $323(4.7)$ & 36.5 & $60(0.9)$ & 48.3 \\
\hline \multicolumn{5}{|l|}{ Youth health clinic } \\
\hline None & 5496 (79.0) & 20.8 & 6314 (92.3) & 32.8 \\
\hline $1-3$ & 1209 (17.4) & 32.4 & 490 (7.2) & 44.5 \\
\hline$\geq 4$ & $256(3.7)$ & 44.5 & $38(0.6)$ & 71.1 \\
\hline \multicolumn{5}{|l|}{ General practitioner } \\
\hline None & 2808 (40.5) & 23.4 & 3653 (53.4) & 36.8 \\
\hline $1-3$ & $3289(47.4)$ & 22.5 & 2729 (39.9) & 29.8 \\
\hline$\geq 4$ & $841(12.1)$ & 27.8 & $453(6.6)$ & 36.0 \\
\hline \multicolumn{5}{|c|}{ Child and adolescent mental health services } \\
\hline None & $6463(93.1)$ & 21.8 & 6590 (96.3) & 32.8 \\
\hline$\geq 1$ & 477 (6.9) & 47.0 & $251(3.7)$ & 62.2 \\
\hline \multicolumn{5}{|l|}{ Health indicators } \\
\hline \multicolumn{5}{|l|}{ Asthma } \\
\hline None & 5730 (86.3) & 23.1 & $5753(86.5)$ & 33.3 \\
\hline Yes & 910 (13.7) & 27.1 & 897 (13.5) & 37.9 \\
\hline \multicolumn{5}{|l|}{ Allergy } \\
\hline None & $3958(59.0)$ & 21.9 & 4261 (63.5) & 33.5 \\
\hline Yes & $2756(41.0)$ & 25.9 & $2448(36.5)$ & 34.4 \\
\hline \multicolumn{5}{|l|}{ Self-perceived health } \\
\hline Very good/good & $5932(86.1)$ & 21.8 & $6227(90.6)$ & 32.8 \\
\hline Not good/poor & 960 (13.9) & 36.8 & $645(9.4)$ & 46.8 \\
\hline \multicolumn{5}{|l|}{ Serious illness/injury past 12 months } \\
\hline None & 5956 (90.8) & 23.1 & $5929(90.1)$ & 33.4 \\
\hline Yes & $606(9.2)$ & 24.1 & $651(9.9)$ & 37.2 \\
\hline \multicolumn{5}{|l|}{ Pain sites reported past 12 months } \\
\hline$<3$ & 3917 (59.6) & 19.6 & 5107 (77.7) & 31.6 \\
\hline$\geq 3$ & $2463(40.4)$ & 29.3 & 1385 (22.3) & 42.2 \\
\hline \multicolumn{5}{|l|}{ HSCL-10 } \\
\hline$<1.6$ & $4391(64.8)$ & 19.3 & $5848(86.6)$ & 31.8 \\
\hline$\geq 1.6$ & 2390 (35.2) & 30.5 & 906 (13.4) & 45.7 \\
\hline \multicolumn{5}{|l|}{ Sociodemographic variables } \\
\hline \multicolumn{5}{|l|}{ Ethnicity } \\
\hline Ethnic Norwegian & $6115(87.1)$ & 22.5 & $6040(87.0)$ & 31.8 \\
\hline First generation immigrant & 580 (8.3) & 36.7 & $546(7.9)$ & 53.7 \\
\hline Second generation immigrant & $324(4.6)$ & 25.0 & 359 (5.2) & 43.7 \\
\hline \multicolumn{5}{|l|}{ Parents' marital status } \\
\hline Married/living together & $4655(66.6)$ & 18.4 & $4600(67.0)$ & 28.8 \\
\hline Other & 2335 (33.4) & 34.2 & 2265(33.0) & 44.1 \\
\hline \multicolumn{5}{|l|}{ Household income } \\
\hline Very good or good & 4212 (60.9) & 20.2 & 4520 (66.2) & 31.9 \\
\hline Mediocre & $2450(35.4)$ & 27.3 & 2096 (30.7) & 36.2 \\
\hline Poor & $250(3.6)$ & 45.6 & 207 (3.0) & 48.3 \\
\hline \multicolumn{5}{|l|}{ Parents' educational level } \\
\hline College/university degree $>4$ years & $1001(14.5)$ & 7.6 & 936 (13.7) & 12.8 \\
\hline College/university degree $\leq 4$ years & 2135 (30.9) & 14.3 & 2142 (31.3) & 24.2 \\
\hline High school & 2867 (41.4) & 29.1 & 2814 (41.1) & 39.5 \\
\hline Primary school & 915 (13.2) & 44.3 & 949 (13.9) & 59.1 \\
\hline
\end{tabular}

Self-reports can imply an underestimation of health service usage, especially use of mental health services. Other health problems than those adjusted for in our analyses could have influenced help-seeking behaviour and failure to complete high school. Yet, disability benefits acquired at a young age were considered to have 
Table 4 Associations between healthcare-seeking behaviour evaluated in 10th-grade adolescents and high school dropout 5 years later

\begin{tabular}{|c|c|c|c|c|}
\hline \multirow[b]{2}{*}{$\begin{array}{l}\text { Self-reported level of } \\
\text { healthcare use }\end{array}$} & \multicolumn{2}{|l|}{ Crude } & \multicolumn{2}{|l|}{ Adjusted† } \\
\hline & $\begin{array}{l}\text { Girls } \\
\text { OR (95\% Cl)‡ }\end{array}$ & $\begin{array}{l}\text { Boys } \\
\text { OR }(95 \% \mathrm{CI})\end{array}$ & $\begin{array}{l}\text { Girls } \\
\text { OR (95\% Cl) }\end{array}$ & $\begin{array}{l}\text { Boys } \\
\text { OR }(95 \% \mathrm{Cl})\end{array}$ \\
\hline \multicolumn{5}{|l|}{ School health services } \\
\hline $1-3$ & $1.15(1.01 \text { to } 1.30)^{*}$ & $1.36(1.19 \text { to } 1.56)^{\star \star \star}$ & $0.82(0.70 \text { to } 0.96)^{*}$ & $1.15(0.97$ to 1.36$)$ \\
\hline$\geq 4$ & $2.02(1.59 \text { to } 2.56)^{\star \star *}$ & $1.93(1.16 \text { to } 3.21)^{*}$ & $0.86(0.63$ to 1.17$)$ & $0.71(0.37$ to 1.36$)$ \\
\hline \multicolumn{5}{|l|}{ Youth health clinic } \\
\hline $1-3$ & $1.83(1.60 \text { to } 2.10)^{\star \star \star}$ & $1.64(1.36 \text { to } 1.97)^{\star \star \star}$ & $1.72(1.45 \text { to } 2.04)^{\star \star \star}$ & $1.16(0.92$ to 1.45$)$ \\
\hline$\geq 4$ & $3.06(2.37 \text { to } 3.95)^{\star \star *}$ & $5.02(2.48 \text { to } 10.14)^{\star * \star}$ & $1.99(1.45 \text { to } 2.73)^{\star \star \star}$ & $2.76(1.24 \text { to } 6.13)^{\star}$ \\
\hline \multicolumn{5}{|l|}{ General practitioner } \\
\hline $1-3$ & 0.95 (0.84 to 1.07$)$ & $0.73(0.65 \text { to } 0.81)^{\star \star \star}$ & $0.89(0.77$ to 1.03$)$ & $0.69(0.61 \text { to } 0.79)^{\star \star \star}$ \\
\hline$\geq 4$ & $1.26(1.06 \text { to } 1.50)^{\star *}$ & $0.96(0.79$ to 1.18$)$ & $0.87(0.69$ to 1.10$)$ & 0.85 (0.66 to 1.09$)$ \\
\hline \multicolumn{5}{|c|}{$\begin{array}{l}\text { Child and adolescent mental health services } \\
\text { None (ref) }\end{array}$} \\
\hline$\geq 1$ & $3.18(2.63 \text { to } 3.84)^{\star \star *}$ & $3.37(2.60 \text { to } 4.37)^{\star \star \star}$ & $2.04(1.60 \text { to } 2.60)^{\star \star \star}$ & $2.85(2.07 \text { to } 3.93)^{\star \star}$ \\
\hline \multicolumn{5}{|c|}{$\begin{array}{l}\text { Investigated using multiple logistic regression analysis. } \\
{ }^{\star} \text { Significant relationship, } \mathrm{p} \leq 0.05 \text {. } \\
{ }^{*} \text { Significant relationship, } \mathrm{p} \leq 0.01 \text {. } \\
{ }^{* *} \text { Significant relationship, } \mathrm{p} \leq 0.001 \text {. } \\
\text { †n the adjusted model use of each health service is adjusted for use of the other healthcare services, health indicators and } \\
\text { sociodemographic variables. } \\
\ddagger \text { All associations were expressed in OR with } 95 \% \mathrm{Cl} \text {. }\end{array}$} \\
\hline
\end{tabular}

been the result of the most serious health disabilities, and were therefore excluded from our sample.

A recent validation study confirms that the HSCL-10 instrument, which we have used to measure mental health problems, is a suitable diagnostic tool for adolescents in this age group, and is also found to be appropriate for use in epidemiological studies. ${ }^{31}$ Although our cut-off point of 1.6 has been validated as optimal for detecting mild, moderate and severe depression in 1416 -year olds of both genders, ${ }^{31}$ it can be argued that this cut-off may be low, and could thereby define an unreasonably large proportion of adolescents as depressed. ${ }^{32} 33$ Another constraint is lack of a measure of other types of mental health problems.

High school dropout has been chosen as the outcome variable because it is an early marker for later work marginalisation and social exclusion. ${ }^{112021}$ Previous studies indicate that those who drop out of high school have a higher risk of becoming dependent on welfare benefits in adult life, including receipt of an early-disability pension. ${ }^{1134} 35$ It can be argued that the 5-year limit is strict, but it is consistent with other studies on school dropout, and few of those who fail to complete high school within 5 years succeed in finishing later. ${ }^{19} 26$

\section{Comparison with previous research}

We do not imply that health service use in adolescence causes high school dropout, rather that it is a proxy for problems which can be independent risk factors for dropout. Although several studies confirm an underuse of healthcare among adolescents who struggle with somatic and mental health issues, ${ }^{1} 36$ both previous research $^{7}$ and the descriptive material in our study, as shown in table 2, confirm that help seekers constitute a group which generally have a greater load of health problems compared with non-seekers, and should receive special attention. Both structural and individual factors influence help seeking. ${ }^{36} 37$ From previous research we know that such sociodemographic characteristics as economic status and parents' educational level influence both help seeking $^{2} 7$ and high school graduation. ${ }^{8} \quad 19$ Health complaints which commonly lead adolescents to seek help can also influence them to drop out. After correcting for such factors in our analyses, we found a negative outcome in adolescents seeking help at the youth health clinic and the mental health services, indicating that they have other challenges that can explain their higher probability of dropping out. However, help seekers may have resources and certain personal qualities that enable them to recognise and cope with their problems-a characteristic which we cannot correct in the analyses. ${ }^{3}$

Youth health clinics in Norway provide free advice and prescriptions for birth control and treatment of sexually transmitted diseases. In addition, it is a low-threshold service centre where adolescents can consult a nurse or a physician about mental health issues. Visiting the youth health clinic multiple times at 15-16 years of age can indicate sexual debut at an early age. We know that adolescent pregnancy is a risk factor for lower 
educational achievement, ${ }^{18}$ but less is known about early sexual activity in general and failure to complete high school. A previous study has shown associations between low-academic achievement and high level of externalising behaviour and early sexual debut in both genders. ${ }^{38}$ A US study on adolescents receiving mental health treatment shows associations between both externalising and internalising psychiatric disorders and sexual risk-taking behaviour. ${ }^{39}$ To the best of our knowledge, there is limited research on boys who attend the youth health clinic or similar services, and there are few boys in our sample with multiple encounters. Those who have multiple encounters, however, have a dropout rate above $70 \%$. Our results indicate that health workers in youth health clinics should be aware of and offer follow-up to adolescents with multiple visits.

In the crude model, adolescent attenders to the school health services generally had a higher level of high school dropout. After adjustments, though, girls with moderate attendance turned out to have slightly lower odds for dropout. A recent US study has found an association between low-to-moderate use of school-based health centres and reduction of dropout for high school students; ${ }^{40}$ a finding which is in line with our result. The American school-based health centres, however, offer a wider range of health services than do school health services in Norway, and are therefore not directly comparable.

We found that consulting the child and adolescent mental health services was associated with lower odds for graduating from high school. As a referral is needed to see the mental health services, we argue that individuals who qualify for specialised therapy usually have relatively severe mental health problems. A previous study has shown that there is a dose-response association between help seeking for mental health problems and symptom load of anxiety and depression. ${ }^{41}$ Furthermore, the early-onset mental disorders have been shown to be associated with lower educational attainment. ${ }^{12}{ }^{13}$ It is not surprising, then, that the outcome in the group consulting mental health services at age 15-16 years is less fortunate.

Boys who saw a GP regularly were more likely to graduate from high school than their peers, although there was no such statistically significant relationship for girls. This finding suggests that, for boys, having a stable relationship with a GP in their adolescent years can have a positive impact. Yet, although we assume that the boys who utilise GP services are consulting for health problems and that they are helped in some way, they may also have individual resources which explain their better outcomes. Teenage boys have a substantially lower use of healthcare services than do girls, including seeing a GP. $^{42}$ They are also more reluctant to seek help for emotional problems unless severely distressed. ${ }^{37} 43$

\section{Implications for policy and practice}

Previous research confirms that adolescents have frequent encounters with the primary healthcare services every year, ${ }^{44} 45$ which is consistent with our findings.
These contacts provide golden opportunities to uncover somatic health problems and mental distress. Health workers in the primary healthcare services should pay particular attention to adolescents with multiple health service encounters and offer follow-up when needed. It is also important to refer to the specialist services when the severity of the condition calls for it. Our results may suggest that by the time adolescents are referred to second-line mental health services, their conditions are well entrenched and the prognosis is consequently more negative.

Youth health clinics are low-threshold services which are visited by a substantial number of adolescents every year-especially young girls. Considering the high probability of dropping out among attenders of this service, as shown in our study, health workers should be advised to focus particularly on these adolescents and the quality of their treatment.

Although girls report more health problems and a higher level of health service usage than boys, they are more likely to graduate from high school-a divergence that calls for a broader approach to the relationship between health and failure to complete high school. More research is needed to disentangle the role of health services in dealing with adolescent health and possible preventive potential for adolescents' symptom load and functional impairment in the following years.

Acknowledgements The data collection was carried out and funded by the Norwegian Institute of Public Health in collaboration with the University of Oslo. The authors also acknowledge statistician Tore Wentzel-Larsen at the Norwegian Centre for Violence and Traumatic Stress Studies/Centre for Child and Adolescent Mental Health, Eastern and Southern Norway, Oslo, Norway for helping with preparing the data for analyses.

Contributors All three authors contributed to the study design, discussions of the results and writing of the final article. LH prepared the data, undertook the primary analyses and the first interpretations and wrote the first draft of the article. $\mathrm{ORH}$ and EOR supervised the analyses and critically reviewed the article. $\mathrm{ORH}$ and EOR also took part in planning and conducting the original baseline survey. All authors approved the submitted version.

Funding The study was funded by the Norwegian Research Council.

\section{Competing interests None.}

Ethics approval The study was approved by the Norwegian Institute of Public Health, Statistics Norway, the Ministry of Education and Research and the Medical Ethics Committee. These institutions gave permission for the use and linkage of the data. The adolescent participants gave written consent to link their questionnaire data to national registers at a later date.

Provenance and peer review Not commissioned; externally peer reviewed.

Data sharing statement No additional data are available.

Open Access This is an Open Access article distributed in accordance with the Creative Commons Attribution Non Commercial (CC BY-NC 3.0) license, which permits others to distribute, remix, adapt, build upon this work noncommercially, and license their derivative works on different terms, provided the original work is properly cited and the use is non-commercial. See: http:// creativecommons.org/licenses/by-nc/3.0/

\section{REFERENCES}

1. Britto MT, Klostermann BK, Bonny AE, et al. Impact of a school-based intervention on access to healthcare for underserved youth. J Adolesc Health 2001;29:116-24. 
2. Eisenberg D, Golberstein E, Gollust SE. Help-seeking and access to mental health care in a university student population. Med Care 2007;45:594-601.

3. Zwaanswijk M, Verhaak PF, Bensing JM, et al. Help seeking for emotional and behavioural problems in children and adolescents: a review of recent literature. Eur Child Adolesc Psychiatry 2003;12:153-61.

4. Mauerhofer A, Berchtold A, Michaud PA, et al. GPs' role in the detection of psychological problems of young people: a population-based study. Br J Gen Pract 2009;59:e308-14.

5. Flament MF, Cohen D, Choquet M, et al. Phenomenology, psychosocial correlates, and treatment seeking in major depression and dysthymia of adolescence. J Am Acad Child Adolesc Psychiatry 2001;40:1070-8.

6. Offer D, Howard KI, Schonert KA, et al. To whom do adolescents turn for help? Differences between disturbed and nondisturbed adolescents. J Am Acad Child Adolesc Psychiatry 1991;30:623-30.

7. Vila M, Kramer T, Obiols JE, et al. Adolescents who are frequent attenders to primary care: contribution of psychosocial factors. Soc Psychiatry Psychiatr Epidemiol 2012;47:323-9.

8. Freudenberg N, Ruglis J. Reframing school dropout as a public health issue. Prev Chronic Dis 2007:4

9. Suhrcke M, de Paz Nieves $C$. The impact of health and health behaviours on educational outcomes in high-income countries: a review of the evidence: Copenhagen, WHO Regional Office for Europe, 2011.

10. Maslow GR, Haydon AA, Ford CA, et al. Young adult outcomes of children growing up with chronic illness: an analysis of the National Longitudinal Study of Adolescent Health. Arch Pediatr Adolesc Med 2011;165:256-61.

11. Gravseth HM, Bjerkedal T, Irgens LM, et al. Life course determinants for early disability pension: a follow-up of Norwegian men and women born 1967-1976. Eur J Epidemiol 2007;22:533-43.

12. Breslau J, Lane M, Sampson N, et al. Mental disorders and subsequent educational attainment in a US national sample. $J$ Psychiatr Res 2008;42:708-16.

13. Stoep AV, Weiss NS, Kuo ES, et al. What proportion of failure to complete secondary school in the US population is attributable to adolescent psychiatric disorder? J Behav Health Serv Res 2003;30:119-24.

14. Fletcher JM. Adolescent depression: diagnosis, treatment, and educational attainment. Health Econ 2008;17:1215-35.

15. Needham BL. Adolescent depressive symptomatology and young adult educational attainment: an examination of gender differences. $J$ Adolesc Health 2009;45:179-86.

16. Markussen E, Seland I. Å redusere bortvalg-bare skolenes ansvar? En undersøkelse av bortvalg ved de videregående skolene i Akershus fylkeskommune skoleåret 2010-2011. NIFU: Nordic Institute for Studies in Innovation, Research and Education, 2012

17. Townsend L, Flisher AJ, King G. A systematic review of the relationship between high school dropout and substance use. Clin Child Fam Psychol Rev 2007;10:295-317.

18. Hofferth SL, Reid L, Mott FL. The effects of early childbearing on schooling over time. Fam Plan Perspect 2001;33:259-67.

19. Bratsberg B, Raaum O, Røed K, et al. Utdannings-og arbeidskarrierer hos unge voksne: Hvor havner ungdom som slutter skolen i ung alder? Frisch Report 3: Ragnar Frisch Centre for Economic Research, 2010.

20. De Ridder KA, Pape K, Johnsen R, et al. School dropout: a major public health challenge: a 10-year prospective study on medical and non-medical social insurance benefits in young adulthood, the Young-HUNT 1 Study (Norway). J Epidemiol Community Health 2012;66:995-1000.

21. Bruusgaard D, Smeby L, Claussen B. Education and disability pension: a stronger association than previously found. Scand J Public Health 2010;38:686-90.
22. Avendano M, Jurges $\mathrm{H}$, Mackenbach JP. Educational level and changes in health across Europe: Iongitudinal results from SHARE. $J$ Eur Soc Policy 2009;19:301-16.

23. Geijerstam C. Tidlig arbeidsledighet og marginalisering. Contributor, Universitetet i Oslo Økonomisk institutt Ragnar Frisch Centre for Economic Research, 2001.

24. Søgaard A, Eide T. The Oslo Health Study (HUBRO)-The Youth part (UNGHUBRO). Aims, Materials and Methods (online), 2005 http://wwwfhino/dav/AD07555E4Bdoc (accessed 24 Jun 2013).

25. http://www.fhi.no/eway/default.aspx?pid=238\&trg=MainArea 5811\&MainArea_5811=5895:0:15,4438:1:0:0:::0:0 (accessed 9 Apr 2013).

26. Falch $\mathrm{T}$, Nyhus $\mathrm{OH}$. High school dropout and labour market attachments among young adults. Centre for Economic research: NTNU, 2009.

27. Breidablik HJ, Meland E, Lydersen S. Self-rated health during adolescence: stability and predictors of change (Young-HUNT study, Norway). Eur J Public Health 2009;19:73-8.

28. Lundberg $\mathrm{O}$, Manderbacka $\mathrm{K}$. Assessing reliability of a measure of self-rated health. Scand J Soc Med 1996;24:218-24.

29. Bair MJ, Robinson RL, Katon W, et al. Depression and pain comorbidity: a literature review. Arch Intern Med 2003;163:2433-45.

30. Strand $\mathrm{BH}$, Dalgard OS, Tambs K, et al. Measuring the mental health status of the Norwegian population: a comparison of the instruments SCL-25, SCL-10, SCL-5 and MHI-5 (SF-36). Nord $J$ Psychiatry 2003;57:113-18.

31. Haavet OR, Sirpal MK, Haugen W, et al. Diagnosis of depressed young people in primary health care-a validation of HSCL-10. Fam Pract 2011;28:233-7.

32. Angold A, Costello EJ, Farmer EM, et al. Impaired but undiagnosed. $J$ Am Acad Child Adolesc Psychiatry 1999;38:129-37.

33. Fergusson DM, Horwood LJ, Ridder EM, et al. Subthreshold depression in adolescence and mental health outcomes in adulthood. Arch Gen Psychiatry 2005;62:66-72.

34. Gjesdal S, Ringdal PR, Haug K, et al. Long-term sickness absence and disability pension with psychiatric diagnoses: a populationbased cohort study. Nord J Psychiatry 2008;62:294-301.

35. Wilford J, McMahon AD, Peters J, et al. Predicting job loss in those off sick. Occup Med 2008;58:99-106.

36. Zwaanswijk M, Van der Ende J, Verhaak PF, et al. Factors associated with adolescent mental health service need and utilization. J Am Acad Child Adolesc Psychiatry 2003;42:692-700.

37. Barker G, Olukoya A, Aggleton P. Young people, social support and help-seeking. Int J Adolesc Med Health 2005;17:315-35.

38. Price MN, Hyde JS. When two isn't better than one: predictors of early sexual activity in adolescence using a cumulative risk model. $J$ Youth Adolesc 2009;38:1059-71.

39. Brown LK, Hadley W, Stewart A, et al. Psychiatric disorders and sexual risk among adolescents in mental health treatment. $J$ Consul Clin Psychol 2010;78:590-7.

40. Kerns SE, Pullmann MD, Walker SC, et al. Adolescent use of school-based health centers and high school dropout. Arch Pediatr Adolesc Med 2011;165:617-23.

41. Zachrisson HD, Rodje K, Mykletun A. Utilization of health services in relation to mental health problems in adolescents: a population based survey. BMC Public Health 2006;6:34.

42. Marcell AV, Klein JD, Fischer I, et al. Male adolescent use of health care services: where are the boys? J Adolesc Health 2002;30:35-43.

43. Biddle L, Gunnell D, Sharp D, et al. Factors influencing help seeking in mentally distressed young adults: a cross-sectional survey. $\mathrm{Br} \mathrm{J}$ Gen Pract 2004;54:248-53.

44. Haavet OR, Straand J, Hjortdahl P, et al. Do negative life experiences predict the health-care-seeking of adolescents? A study of 10th-year students in Oslo, Norway. J Adolesc Health 2005;37:128-34.

45. Santelli J, Klein J, Graff C, et al. Reliability in adolescent reporting of clinician counseling, health care use, and health behaviors. Med Care 2002;40:26-37. 